- Technical Report

\title{
Fire Hazard Assessment of New Automotive Battery Materials Using SDS Information
}

\author{
Juri Kida ${ }^{1}$ and Takashiro Akitsu ${ }^{1}$ \\ ${ }^{1}$ Department of Chemistry, Faculty of Science, Tokyo University of Science, Japan
}

\begin{abstract}
This study uses a safety data sheet (SDS), which describes the characteristics and hazards associated with a chemical substance, to determine the hazards associated with battery materials. Furthermore, we investigated whether fires in electric vehicles caused by vehicle-mounted batteries can be predicted using SDSs alone. In addition, we aimed to overcome the limitations associated with fire prediction in electric vehicles using an SDS-based artificial intelligence (AI) method. We found that fires caused by battery material could be accurately predicted using SDSs; however, fires caused by thermal runaway or fires of unknown or artificial origins could not be predicted by SDSs alone. Results demonstrate that when AI is utilized for predicting and extinguishing fires in electric vehicles, it is important to consider the hazards associated with the battery material and also to analyze fires that have occurred in the past along with effective fire extinguishing methods. Although there are limitations at the organizational and developmental stages of information provided to AI, if implemented, it can be applied for predicting fires in electric vehicles and in other devices.
\end{abstract}

Keywords : automotive battery, SDS, prediction of fire hazard, AI

\section{INTRODUCTION}

\subsection{Challenges Arising from the Increasing Numbers of Electric Vehicles}

Increasingly strict regulations concerning exhaust gas from automobiles, including $\mathrm{CO}_{2}, \mathrm{NO}_{\mathrm{x}}$, and $\mathrm{SO}_{\mathrm{x}}$, are being implemented worldwide to decrease air pollution and protect the global environment. Consequently, major automobile manufacturers have promoted the development and popularization of electric vehicles. These can be hybridelectric vehicles (HEVs), which feature an internal combustion engine and a batterypowered electric motor, or fuel cell vehicles (FCVs), in which electricity generated by a loaded fuel cell powers the motor. Figure 1 highlights the steady increase in the number of electric vehicles in Japan since 2011. 


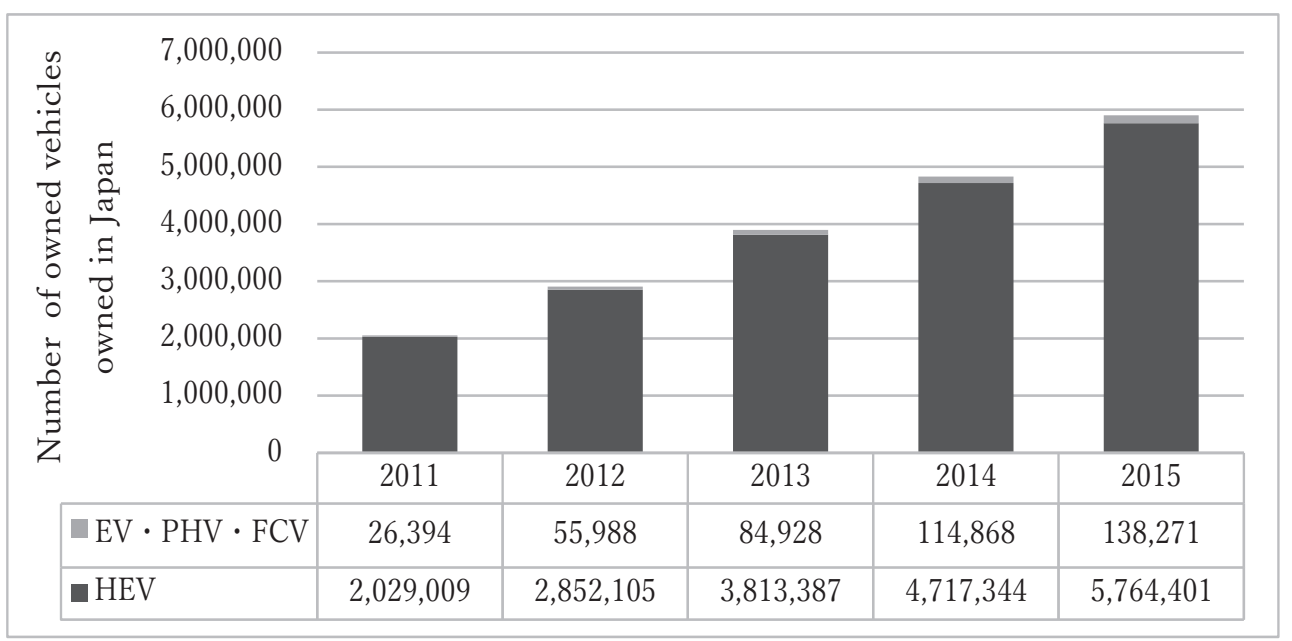

Figure 1 Number of electric vehicles in Japan [1].

The development of electric vehicles has progressed rapidly and they have attracted increasing attention owing to the incorporation of lithium-ion batteries and polymer electrolyte fuel cells. However, a major drawback with these batteries is the presence of flammable components, which pose a serious or even catastrophic fire risk. According to the Tokyo Metropolitan Fire Department, approximately 65 fire cases were reported in Tokyo during the use or charging of lithium-ion batteries between 2011 and 2015 . As of the end of November 2016, 50 similar fire cases were reported [2]. Figure 2 shows the remains of a battery of an electric-assist bicycle that caught fire and burned due to overcharging.

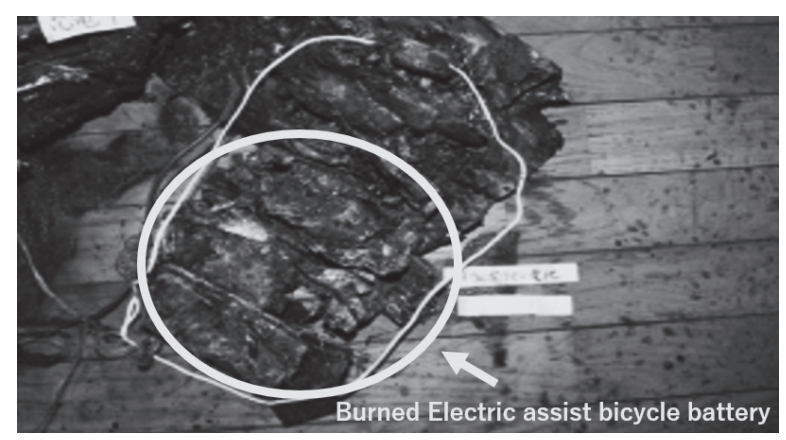

Figure 2 Burned lithium-ion battery [2].

\subsection{Electric Vebicles and Batteries}

This section describes the electric vehicles and batteries examined in the proposed study. Electric vehicle is a general term for vehicles that use an electric motor for propulsion. Such vehicles are further classified according to their power generation method and chargeability. Table 1 lists the main types of electric vehicles. 
Table 1 Types of electric vehicles [1].

\begin{tabular}{|c|c|}
\hline Name & Function \\
\hline Battery Electric Vehicle (BEV) & $\begin{array}{c}\text { Driving with only secondary batteries } \\
\text { (storage batteries) }\end{array}$ \\
\hline Hybrid-Electric Vehicle (HEV) & $\begin{array}{c}\text { A hybrid vehicle equipped with a } \\
\text { secondary battery and motor in an internal } \\
\text { combustion locomotive }\end{array}$ \\
\hline Plug-in Hybrid-Electric Vehicle (PHEV) & $\begin{array}{c}\text { The number of HEV secondary batteries } \\
\text { can be increased, and external batteries } \\
\text { can be externally charged like BEVs }\end{array}$ \\
\hline Fuel Cell Vehicle (FCV) & Automobile with fuel cell and motor \\
\hline
\end{tabular}

Chemical batteries generate electricity via a redox reaction. They serve as the power source for electric vehicles. Currently, chemical batteries are categorized as follows: primary batteries, such as dry batteries that cannot be recharged; secondary batteries, such as rechargeable lead-acid and lithium-ion batteries; and fuel cells, wherein an oxidation-reduction reaction is sustained by a continuous supply of external fuel. Electric vehicles are equipped with secondary batteries or fuel cells that can be reused by recharging or refueling. Chemical batteries should comprise the correct assembly of the following six items [3]: (1) positive electrode active material (cathode), which is an oxidant that accepts electrons; (2) negative electrode active material (anode), which is a reductant that donates electrons; (3) electrolyte, which is a medium with ionic conductivity; (4) separator, which is a membrane that partitions the oxidants and reductants; (5) current collector, which is a material through which the generated electricity flows, thereby feeding the system; and (6) case, which is a container for storing (1)-(5). A schematic of a battery is shown in Figure 3.

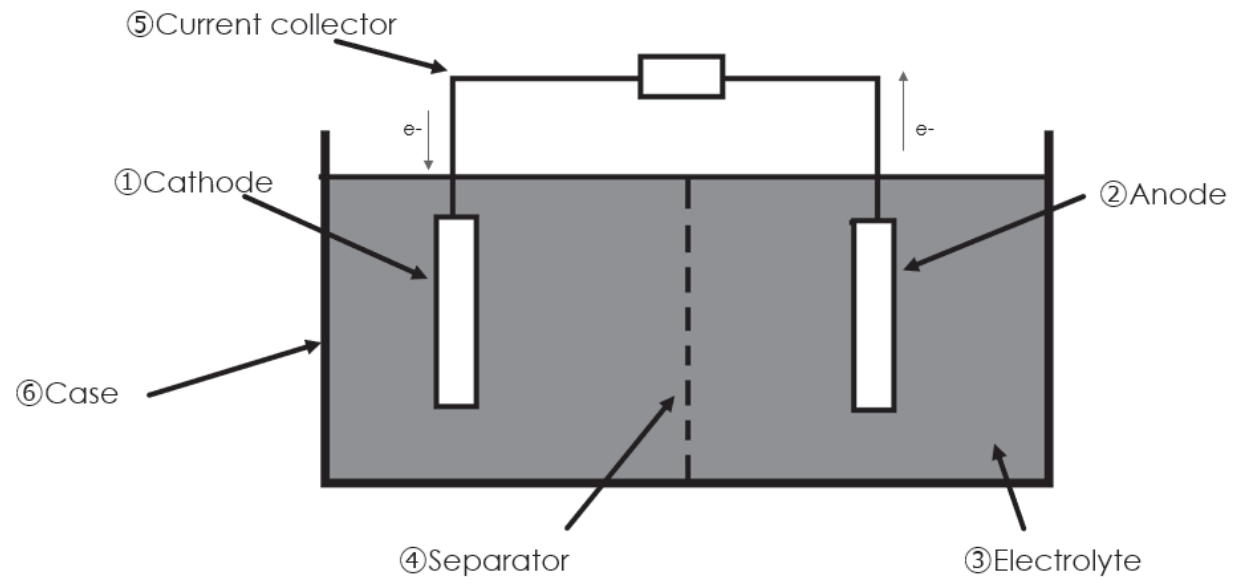

Figure 3 Schematic battery diagram (during discharge) [3]. 
In a battery, transfer of electrons between atoms, ions or compounds occurs via an oxidation reaction (Equation 1), in which a substance releases electrons, and a reduction reaction (Equation 2), in which another substance accepts electrons. The global battery redox reaction is expressed in Equation 3.

$$
\begin{aligned}
& \mathrm{A} \rightarrow \mathrm{A}^{\mathrm{n}+}+\mathrm{ne}^{-}, \\
& \mathrm{B}^{\mathrm{n}+}+\mathrm{ne}^{-} \rightarrow \mathrm{B}, \\
& \mathrm{A}+\mathrm{B}^{\mathrm{n}+}+\mathrm{ne}^{-} \rightarrow \mathrm{A}^{\mathrm{n}+}+\mathrm{B}+\mathrm{ne}^{-}, \\
& \mathrm{A}+\mathrm{B}^{\mathrm{n}+} \rightarrow \mathrm{A}^{\mathrm{n}+}+\mathrm{B} .
\end{aligned}
$$

During discharge, $\mathrm{A}$ is the reducing agent (anode) and B is the oxidant (cathode). Hence, the oxidation reaction occurs at the negative electrode, while the reduction reaction occurs at the positive electrode.

Lithium-ion storage batteries are used in most electric vehicles owing to their comparatively high output and low degradation rate. In these batteries, lithium ions move between the positive and negative electrodes through the electrolytic solution to perform charging and discharging, as shown in Figure 4.

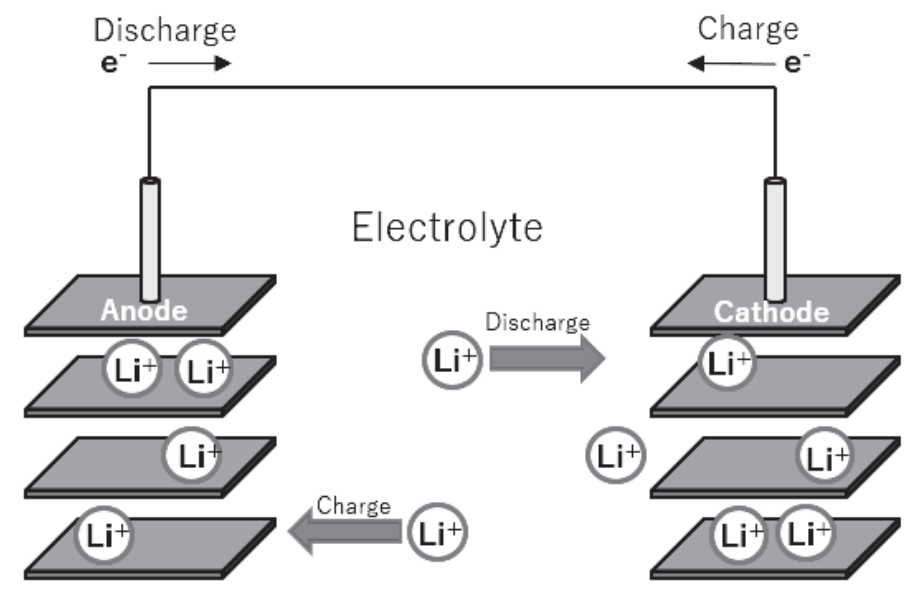

Figure 4 Schematic of a lithium-ion battery [4].

Generally, the negative electrode consists of graphite, while the positive electrode is made of lithium cobaltate. The reactions at the electrodes proceed as follows (Equations 4 and 5):

$$
\begin{aligned}
& \mathrm{Li}_{\mathrm{x}} \mathrm{C}_{6} \leftrightarrows \mathrm{C}_{6}+\mathrm{xLi}^{+}+\mathrm{xe}^{-}(0 \leqq \mathrm{x} \leqq 1) \\
& \mathrm{Li}_{1-\mathrm{x}} \mathrm{CoO}_{2}+\mathrm{xLi}^{+}+\mathrm{xe}^{-} \leftrightarrows \mathrm{LiCoO}_{2}(0 \leqq \mathrm{x} \leqq 0.45)
\end{aligned}
$$

When metallic lithium ( $\mathrm{Li})$ is used as the negative electrode, lithium is deposited during charging (the reverse reaction of Equation 4), causing a short circuit. To minimize the risk 
of battery ignition or explosion due to the heat generated by a short circuit, graphite with a layered structure is used at the negative electrode because lithium ions from the electrolyte diffuse within the layered structure.

Lithium-ion batteries face the risk of thermal runaway, a phenomenon in which heat generated at one part of the battery (as a result of overheating, overcharging, overdischarging, an external short circuit, or an internal short circuit) triggers heat generation in other parts of the battery, causing the inner battery temperature to continuously rise, often to a destructive extent. The occurrence of thermal runaway in lithium-ion batteries is associated with the risk of vaporization and ignition or explosion of the flammable electrolyte.

Fuel cells used in FCVs are devices that transform the chemical energy of the fuel, such as $\mathrm{H}_{2}$, $\mathrm{CO}$, or $\mathrm{C}_{2} \mathrm{H}_{5} \mathrm{OH}$, to electrical energy via an electrochemical reaction. Such devices have attracted considerable attention as environmentally friendly energy sources because they do not emit $\mathrm{CO}_{2}$ during power generation. Table 2 lists the main types of fuel cells. 
Table 2 Types of fuel cells [5].

\begin{tabular}{|c|c|c|c|c|}
\hline & $\begin{array}{c}\text { Polymer electrolyte } \\
\text { fuel cell (PEFC) }\end{array}$ & $\begin{array}{c}\text { Phosphoric acid fuel } \\
\text { cell (PAFC) }\end{array}$ & $\begin{array}{l}\text { Molten carbonate } \\
\text { fuel cell (MCFC) }\end{array}$ & $\begin{array}{c}\text { Solid oxide fuel cell } \\
\text { (SOFC) }\end{array}$ \\
\hline Electrolytes & $\begin{array}{c}\text { Proton conductive } \\
\text { polymer membrane }\end{array}$ & $\begin{array}{l}\text { Phosphoric acid } \\
\text { aqueous solution }\end{array}$ & $\begin{array}{l}\text { Molten carbonate } \\
\quad(\mathrm{LiK}, \mathrm{LiNa})\end{array}$ & $\begin{array}{c}\text { Oxygen ion } \\
\text { conducting ceramics }\end{array}$ \\
\hline $\begin{array}{l}\text { Conductive ion } \\
\text { Species }\end{array}$ & $\mathrm{H}^{+}$ & $\mathrm{H}^{+}$ & $\mathrm{CO}_{3}$ & $0^{2-}$ \\
\hline $\begin{array}{l}\text { Operating } \\
\text { temperature }\end{array}$ & $80^{\circ} \mathrm{C}$ & $200{ }^{\circ} \mathrm{C}$ & $600-700{ }^{\circ} \mathrm{C}$ & $700-1000{ }^{\circ} \mathrm{C}$ \\
\hline $\begin{array}{l}\text { Available source } \\
\text { materials }\end{array}$ & $\begin{array}{l}\text { Hydrogen } \\
\text { Natural gas } \\
\text { Methanol }\end{array}$ & $\begin{array}{l}\text { Natural gas } \\
\text { LPG } \\
\text { Methanol }\end{array}$ & $\begin{array}{l}\text { Natural gas } \\
\text { LPG } \\
\text { Coal } \\
\text { Biomass }\end{array}$ & $\begin{array}{l}\text { Natural gas } \\
\text { LPG } \\
\text { Coal } \\
\text { Biomass }\end{array}$ \\
\hline $\begin{array}{l}\text { Power generation } \\
\text { efficiency }\end{array}$ & $30-40 \%$ & $35-45 \%$ & $40-65 \%$ & $40-65 \%$ \\
\hline Application areas & $\begin{array}{l}\text { Distributed power } \\
\text { supply } \\
\text { Power supply for } \\
\text { movement }\end{array}$ & $\begin{array}{l}\text { Thermal power } \\
\text { Alternative power } \\
\text { source } \\
\text { Distributed power } \\
\text { supply }\end{array}$ & $\begin{array}{l}\text { Thermal power } \\
\text { Alternative power } \\
\text { source } \\
\text { Distributed power } \\
\text { supply }\end{array}$ & $\begin{array}{l}\text { Thermal power } \\
\text { Alternative power } \\
\text { source } \\
\text { Distributed power } \\
\text { supply }\end{array}$ \\
\hline Features / remarks & $\begin{array}{l}\text { Low temperature } \\
\text { operation } \\
\text { Miniaturization } \\
\text { possible (for } \\
\text { movement) } \\
\text { High energy density } \\
\text { Good operation } \\
\text { Product } \\
\text { commercialization }\end{array}$ & Implementation & $\begin{array}{l}\text { High power } \\
\text { generation } \\
\text { efficiency } \\
\text { Internal } \\
\text { modification is } \\
\text { possible } \\
\text { No precious metal } \\
\text { catalyst required }\end{array}$ & $\begin{array}{l}\text { High power generation } \\
\text { efficiency } \\
\text { Internal modification } \\
\text { is possible } \\
\text { No precious metal } \\
\text { catalyst required } \\
\text { Use of high- } \\
\text { temperature exhaust } \\
\text { heat during verification } \\
\text { test }\end{array}$ \\
\hline
\end{tabular}

Among fuel cells, the polymer electrolyte fuel cell operates at a low temperature, is amenable to miniaturization, and possesses a high energy density. Therefore, it is commonly utilized as a power source for electric vehicles and similar devices. Figure 5 presents a power generation principle diagram of polymer electrolyte fuel cells. 


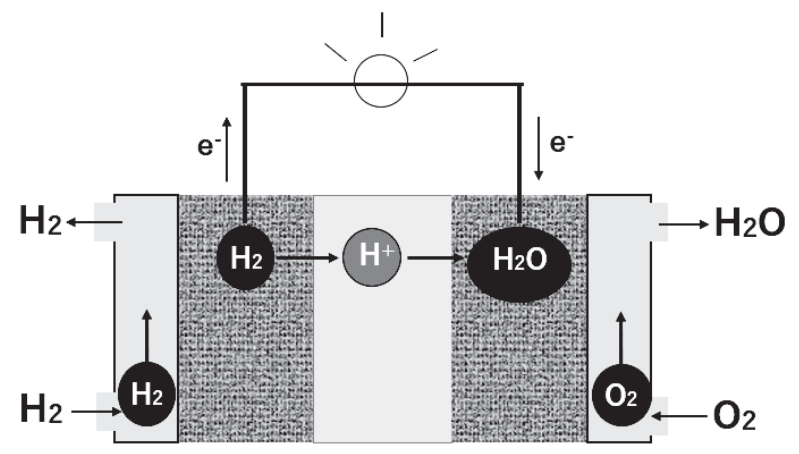

Figure 5 Power generation principle in polymer electrolyte fuel cells [5].

In polymer electrolyte fuel cells, hydrogen fuel is oxidized at the negative electrode, thereby producing protons $\left(\mathrm{H}^{+}\right)$that cross the solid electrolytic membrane and electrons that flow through an external circuit. At the negative electrode, oxygen is reduced by the incoming electrons and combines with the protons to form water $\left(\mathrm{H}_{2} \mathrm{O}\right)$. The reactions at the negative and positive electrodes are shown in Equations 6 and 7, respectively.

$$
\begin{aligned}
& \mathrm{H}_{2} \rightarrow 2 \mathrm{H}^{+}+2 \mathrm{e}^{-}, \\
& \mathrm{O}_{2}+2 \mathrm{H}^{+}+2 \mathrm{e}^{-} \rightarrow \mathrm{H}_{2} \mathrm{O} .
\end{aligned}
$$

\subsection{Safety Data Sheet}

A safety data sheet (SDS) describes the hazards associated with the chemical substances. An SDS is issued by the reagent manufacturing company at the time of selling a product containing chemical substances. An SDS describes the properties and safety and hazard information of chemicals; it serves as a basis for conducting experiments.

Normally, battery manufacturers perform battery safety tests prior to shipment. Such tests are generally conducted on the entire battery and do not consider the SDSs of the individual components. For example, the international safety standard for electric vehicles (UN ECE R 100-02) includes tests on vibration, thermal shock and cycling, mechanical shock, mechanical integrity, fire resistance, external short circuit protection, overcharge protection, overdischarge protection, and overtemperature protection [1].

In this study, we investigate the danger of chemical fires in batteries by examining the battery materials. In contrast to the conventional safety assessment, our investigations focus on the analysis of the hazard information of battery materials contained in their SDSs for the prediction of potential fires. 


\subsection{Required Disaster Prevention Technology}

The Fire and Disaster Prevention Science and Technology Advanced Strategic Plan 2018 and a white paper on firefighting (special feature 8, 2018) introduce examples of the current fire department's research and development of systems using artificial intelligence (AI) and robots, among other tools. The Fire and Disaster Prevention Science and Technology Advancement Strategic Plan was formulated by the Fire and Disaster Management Agency of the Ministry of Internal Affairs and Communications to promote and reinforce the importance of fire and disaster prevention among personnel in industry, academia, and the government. Its primary aim is to enhance the incorporation of science and technology into fire and disaster prevention. Since its formulation in 2001 it has been revised every five years, and an outline of the latest revision (2018) was published in the white paper. The Firefighting Disaster Prevention Science and Technology Advancement Strategy Plan 2018 states: “... Developing and disseminating a fire fighting robot that responds to fires in oil complexes, etc., a rapid information management system using drones in the event of a fire" [6]. In the future, construction of disaster prevention systems employing the latest technologies, such as drones and AI, is required, and it is assumed that these technologies can also be beneficially applied to fire risk prediction.

In a previous study [24], we used SDSs to predict the risk of fire in chemistry experiments performed by students at a compulsory lecture at the Tokyo University of Science. The results suggest that numerous chemistry experiment fires can be predicted, unless they are caused by carelessness or a poor understanding of material properties and experimental scales.

AI can process significant amount of data, thereby exceeding the human capabilities of obtaining data. Therefore, it can serve as a useful tool for fire risk prediction. However, there are some shortcomings associated with AI, which include the inability to read line spaces and lack of organized information provided for learning.

Herein, the focus of fire risk prediction was shifted from chemical experiments to batteries, in-vehicle batteries in particular, to determine the fire risk associated with the electric vehicles, which has increased rapidly in recent years. This study primarily aims to obtain hazard information from the SDSs of the substances contained in batteries. Then, we determine whether and under what circumstances such fires can be predicted. Finally, limitations associated with SDS-based AI fire prediction in electric vehicles are discussed, and solutions are proposed. 


\section{METHODS}

\subsection{Investigation of Fire Cases}

From the Fire Handbook [1], we considered a case wherein a lithium-ion battery caused fire and a case wherein a fire originated in the same gas container as the fuel cell in a compressed natural gas (CNG) bus. In the seven fire cases listed in the Fire Handbook, the BEV is stated to be equipped with lithium-ion batteries [1]. An accident caused by a moving electric vehicle was considered. Cases wherein the battery was not the direct cause of fire, such as those resulting from natural disasters or parts other than the vehicle's battery pack, were excluded from the study.

As of 2018, FCVs were not ubiquitous, and no fire cases had been reported. Therefore, we included one of the two $\mathrm{CNGV}^{* 1}$ fire cases from the Fire Handbook [1] using the natural gas as an approximation for hydrogen gas because the CFRP composite containers $^{* 2}$ are commonly used in both CNGVs and FCVs. The FCV safety assessment is similar to the full flame exposure test applied to CNGVs. Hence, the approximation of natural gas for hydrogen gas is appropriate.

* 1 CNGV: Natural Gas Vehicle

* 2 CFRP: Carbon Fiber Reinforced Plastics

\subsection{Investigation of Substances Contained in Batteries}

The following information was extracted from battery material SDSs, where the numbers indicate the corresponding SDS sections: 2. Hazard summary (GHS classification, other hazards); 9. Physical and chemical properties; 10. Stability and reactivity (stability, possibility of hazardous reactions, incompatible materials, etc.); and 15. Applicable laws. In all cases, the absence of danger for substances lacking information or containing information unrelated to fire (e.g., 2. carcinogenicity, reproductive toxicity, etc.) was verified. Conversely, substances whose SDSs contained information in the abovementioned sections were defined as "substances with fire hazard" and taken into consideration.

\subsection{Discussion}

We examined whether fire cases could be predicted based on the substance's hazards listed in its SDS. If information other than that in the SDS would have been required (e.g., the conditions of batteries and vehicles), the case was regarded as difficult to predict. 


\section{RESULTS}

\subsection{Fire Examples}

The following two cases were selected in our investigations.

\subsubsection{Fire Example (1)}

"In March 2013, one of the G car battery packs that was being charged for finished product inspection at the EV battery pack assembly plant overheated and ignited about an hour later. It is reported that the cause of the failure was the excessive impact applied during the inspection process, which caused an internal short circuit due to deformation of the parts inside the lithium-ion battery and generation of metal pieces."

\subsubsection{Fire Example (2)}

“...Shows an example of a CNG bus fuel container that ruptured during a fire. The ruptured CFRP composite container was equipped with a thermally activated safety valve that had passed the full flame exposure test described above. A flame was ejected from the hatch, and only the central part of the container loaded on the roof was exposed to the flame; therefore, the heat was not transmitted to the heat-actuated safety valve installed at the end of the container, and the safety valve was not activated. The container broke without."

\subsection{The Materials of Batteries}

The following sections list lithium-ion battery and fuel cell materials.

\subsubsection{Lithium-Ion Battery Materials [4]}

Positive electrode: Lithium cobaltate $\mathrm{LiCoO}_{2}$ (layered rock-salt structure), lithium manganate $\mathrm{LiMn}_{2} \mathrm{O}_{4}$ (spinel structure), olivine-type lithium iron phosphate $\mathrm{LiFePO}_{4}$ (used as particles and carbon-coated).

Negative electrode: Graphite $\left(\mathrm{LiO}_{6}\right)$ and titanium oxide $\left(\mathrm{Li}_{4} \mathrm{Ti}_{5} \mathrm{O}_{12}\right)$, among others.

Electrolyte: Generally, 1.0 M or 2.0 $\mathrm{M} \mathrm{LiPF}_{6}$ in an organic solvent, such as dimethyl carbonate (DMC), ethyl methyl carbonate (EMC), diethyl carbonate (DEC), propylene carbonate (PC), or a mixture thereof.

Current collector: $\mathrm{Al}$ foil (positive electrode), $\mathrm{Cu}$ foil (negative electrode).

Separator: Polyolefin porous membrane.

\subsubsection{Materials for Polymer Electrolyte Fuel Cells [5]}

Electrolytes: Proton conductive polymer membrane (Nafion), Nafion dispersion.

Fuel: $\mathrm{H}_{2}, \mathrm{CNG}, \mathrm{CH}_{3} \mathrm{OH}$.

Oxidizing agent: $\mathrm{O}_{2}$.

Electrode: Pt or Pt alloys. 


\subsection{Hazard Information of Battery Materials with Fire Hazard}

Table 3 presents battery materials that have a risk of fire, along with the information extracted from their SDSs.

Table 3 Hazardous materials for lithium-ion batteries.

\begin{tabular}{|c|c|}
\hline Dangerous substances & Hazard information \\
\hline \begin{tabular}{|l} 
Positive electrode \\
$\cdot \mathrm{LiCoO}_{2}[7]$ \\
$\cdot \mathrm{LiMn}_{2} \mathrm{O}_{4}[8]$ \\
$\cdot \mathrm{LiFePO}_{4}[9]$ \\
Negative electrode \\
$\cdot$ Graphite $\left(\mathrm{LiO}_{6}\right)[10]$ \\
$\cdot$ Titanium oxide $\left(\mathrm{Li}_{4} \mathrm{Ti}_{5} \mathrm{O}_{12}\right)[11]$
\end{tabular} & $\begin{array}{c}\text { 10.5 Incompatible materials } \\
\text { Strong oxidizing agents }\end{array}$ \\
\hline \begin{tabular}{|l} 
Separator \\
$\cdot$ Polyolefin porous membrane [12]
\end{tabular} & $\begin{array}{l}\text { 2. Hazard summary } \\
\text { Hazard: When heated above } 300{ }^{\circ} \mathrm{C} \text { for a long time, it } \\
\text { decomposes and generates carbon monoxide, carbon dioxide, etc. } \\
\text { 15. Applicable laws: Fire Service Act } \\
\text { Designated combustibles: Synthetic resins (others) } 3000 \mathrm{~kg} \text {. }\end{array}$ \\
\hline $\begin{array}{l}\text { Electrolytes } \\
\cdot 1.0 \mathrm{M} \mathrm{LiPF}_{6} \text { in DMC [13] }\end{array}$ & $\begin{array}{l}\text { 2.1 GHS classification } \\
\text { Flammable liquids (category 2) } \\
\text { 2.2 GHS label elements, including precautionary statements } \\
\text { H225 Highly flammable liquid and vapor. } \\
\text { P210 Keep away from heat/sparks/open flames/hot surfaces. No } \\
\text { smoking. } \\
\text { P260 Do not breathe dust/fumes/gas/mist/vapors/spray. } \\
\text { P370 + P378 in case of fire: Use dry powder or dry sand to } \\
\text { extinguish. } \\
\text { 9.1 Information on basic physical and chemical properties } \\
\text { g) Flash point } 20^{\circ} \mathrm{C} \text {. } \\
\text { 10.4 Conditions to avoid } \\
\text { Reacts dangerously with glass, resulting in heat, flames, and/or } \\
\text { sparks. } \\
\text { 10.5 Incompatible materials } \\
\text { Strong oxidizing agents, acids, bases, reducing agents, steel (all } \\
\text { types and surface treatments), glass. } \\
\text { 15.1 Safety, health, and environmental regulations/legislation } \\
\text { specific for the substance or mixture. National regulatory } \\
\text { information. } \\
\text { Fire Service Law: Group 4: Flammable liquids, type } 1 \text { petroleum } \\
\text { hazardous rank II, water-insoluble liquid. }\end{array}$ \\
\hline
\end{tabular}




\begin{tabular}{|c|c|}
\hline - $1.0 \mathrm{M} \mathrm{LiPF}_{6}$ in $\mathrm{EMC} \mathrm{[14]}$ & $\begin{array}{l}\text { 2.1 GHS classification: Flammable liquids (category 3). } \\
\text { 2.2 GHS label elements, including precautionary statements } \\
\text { H226 Flammable liquid and vapor. } \\
\text { P210 Keep away from heat/sparks/open flames/hot surfaces. No } \\
\text { smoking. } \\
\text { P260 Do not breathe dust/fumes/gas/ mist/vapors/spray. } \\
\text { P370 + P378 in case of fire: Use dry powder or dry sand to } \\
\text { extinguish. } \\
\text { 9.1 Information on basic physical and chemical properties } \\
\text { g) Flash point } 25^{\circ} \mathrm{C} \text {. } \\
\text { 10.4 Conditions to avoid } \\
\text { Heat, flames, and sparks. Reacts dangerously with glass. } \\
\text { 10.5 Incompatible materials } \\
\text { Strong oxidizing agents, acids, bases, reducing agents, steel (all } \\
\text { types and surface treatments), and glass } \\
\text { 15.1 Safety, health and environmental regulations/legislation } \\
\text { specific for the substance or mixture. National regulatory } \\
\text { information. } \\
\text { Fire Service Law: Group 4: Flammable liquids, type } 2 \text { petroleum } \\
\text { hazardous rank II,I water-insoluble liquid }\end{array}$ \\
\hline $\begin{array}{l}\text { Electrolytes } \\
\cdot 1.0 \mathrm{M} \mathrm{LiPF}_{6} \text { in DEC [15] }\end{array}$ & $\begin{array}{l}\text { 2.1 GHS classification } \\
\text { Flammable liquids (category 3) } \\
\text { 2.2 GHS label elements, including precautionary statements } \\
\text { H226 Flammable liquid and vapor. } \\
\text { P210 Keep away from heat/sparks/open flames/hot surfaces. No } \\
\text { smoking. } \\
\text { P233 Keep container tightly closed. } \\
\text { P240 Ground/bond container and receiving equipment. } \\
\text { P241 Use explosion-proof electrical/ventilating/ lighting/ } \\
\text { equipment. } \\
\text { P242 Use only non-sparking tools. } \\
\text { P243 Take precautionary measures against static discharge. } \\
\text { 9.1 Information on basic physical and chemical properties } \\
\text { g) Flash point } 30{ }^{\circ} \text { C. } \\
\text { 10.4 Conditions to avoid } \\
\text { Reacts dangerously with glass, producing heat, flames, and } \\
\text { sparks. } \\
\text { 10.5 Incompatible materials } \\
\text { Strong oxidizing agents, acids, bases, reducing agents, steel (all } \\
\text { types and surface treatments), and glass. } \\
\text { 15.1 Safety, health, and environmental regulations/legislation } \\
\text { specific for the substance or mixture. National regulatory } \\
\text { information. } \\
\text { Fire Service Law: Group 4: Flammable liquids, type } 2 \text { petroleum } \\
\text { hazardous rank III, water-insoluble liquid }\end{array}$ \\
\hline$\cdot 1.0 \mathrm{M} \mathrm{LiPF}_{6} \mathrm{i}$ & $\begin{array}{l}\text { 9.1 Information on basic physical and chemical properties } \\
\text { g) Flash point } 130^{\circ} \mathrm{C} \text {. } \\
\text { 10.4 Conditions to avoid } \\
\text { Reacts dangerously with glass } \\
\text { 10.5 Incompatible materials } \\
\text { Strong oxidizing agents, acids, bases, reducing agents, steel (all } \\
\text { types and surface treatments), and glass }\end{array}$ \\
\hline
\end{tabular}


Table 4 Dangerous substances in fuel cells.

\begin{tabular}{|c|c|}
\hline Dangerous substances & Hazard information \\
\hline \begin{tabular}{|l} 
Electrolytes \\
$\cdot$ Proton conductive polymer \\
membrane (Nafion) [17]
\end{tabular} & $\begin{array}{l}\text { 10.4 Conditions to avoid } \\
\text { Avoid moisture. } \\
\text { 10.5 Incompatible materials } \\
\text { Strong oxidizing agents, strong acids. }\end{array}$ \\
\hline Nafion dispersion [18] & $\begin{array}{l}\text { 2.1 Classification of the substance or mixture } \\
\text { Flammable liquids (category 2). } \\
\text { 2.2 GHS label elements, including precautionary statements } \\
\text { H225 Highly flammable liquid and vapor. } \\
\text { P210 Keep away from heat/sparks/open flames/hot surfaces. No } \\
\text { smoking. } \\
\text { P233 Keep container tightly closed. } \\
\text { P240 Ground/bond container and receiving equipment. } \\
\text { P241 Use explosion-proof electrical/ventilating/lighting/ } \\
\text { equipment. } \\
\text { P242 Use only non-sparking tools. } \\
\text { P243 Take precautionary measures against static discharge. } \\
\text { 9.1 Information on basic physical and chemical properties } \\
\text { g) Flash point } 20^{\circ} \mathrm{C} \text { - closed cup. } \\
\text { 10.4 Conditions to avoid } \\
\text { Heat, flames, and sparks. } \\
\text { 15.1 Safety, health, and environmental regulations/legislation } \\
\text { specific for the substance or mixture. National regulatory } \\
\text { information. } \\
\text { Fire Service Law: Group 4: Flammable liquids, type } 1 \text { petroleum } \\
\text { hazardous rank II, water-insoluble liquid. }\end{array}$ \\
\hline \begin{tabular}{|l|} 
Fuel \\
$\cdot \mathrm{H}_{2}[19]$
\end{tabular} & $\begin{array}{l}\text { 2.1 Classification of the substance or mixture } \\
\text { Flammable gases (category 1). } \\
\text { Gases under pressure (compressed gas). } \\
\text { 2.2 GHS label elements, including precautionary statements } \\
\text { H220 Extremely flammable gas. } \\
\text { H280 Contains gas under pressure; may explode if heated. } \\
\text { P210 Keep away from heat, hot surfaces, sparks, open flames, } \\
\text { and other ignition sources. No smoking. } \\
\text { P377 Leaking gas fire: Do not extinguish, unless leak can be } \\
\text { stopped safely. } \\
\text { P381 Eliminate all ignition sources, if safe to do so. } \\
\text { P410 + P403 Protect from sunlight. Store in a well-ventilated } \\
\text { location. } \\
\text { 9.1 Information on basic physical and chemical properties } \\
\text { g) Flash point <-150 }{ }^{\circ} \mathrm{C}-\text { closed cup. } \\
\text { j) Upper/lower flammability or explosive limits } \\
\text { Upper explosion limit: } 74.2 \% \text { (V). } \\
\text { Lower explosion limit: } 4 \% \text { (V). } \\
\text { 10.4 Conditions to avoid } \\
\text { Heat, flames, and sparks. } \\
\text { 10.5 Incompatible materials } \\
\text { Oxidizing agents. }\end{array}$ \\
\hline
\end{tabular}




\begin{tabular}{|c|c|}
\hline $\begin{array}{l}\text { CNG (compressed natural gas) } \\
{[20]}\end{array}$ & $\begin{array}{l}2 \text { Hazards identification } \\
\text { Press. Gas (compressed gas): Contains gas under pressure; may } \\
\text { explode if heated. } \\
\text { Flam. Gas 1: Extremely flammable gas } \\
\text { H280 Contains gas under pressure; may explode if heated. } \\
\text { H220 Extremely flammable gas. } \\
\text { P210 Keep away from heat/sparks/open flames/hot surfaces. No } \\
\text { smoking. } \\
\text { P377 Leaking gas fire: Do not extinguish, unless leak can be } \\
\text { stopped safely. } \\
\text { P381 Eliminate all ignition sources, if safe to do so. } \\
9 \text { Physical and chemical properties } \\
\text { Flammability range: } 4.4-15 \% \text { (V). } \\
10 \text { Stability and reactivity } \\
\text { Can form an explosive mixture with air. May react violently } \\
\text { with oxidants. }\end{array}$ \\
\hline \begin{tabular}{|l|} 
Fuel \\
$\cdot \mathrm{CH}_{3} \mathrm{OH}[21]$
\end{tabular} & $\begin{array}{l}\text { 2.1 Classification of the substance or mixture } \\
\text { Flammable liquids (category 2). } \\
\text { 2.2 GHS label elements, including precautionary statements } \\
\text { H225 Highly flammable liquid and vapor. } \\
\text { P210 Keep away from heat, hot surfaces, sparks, open flames, } \\
\text { and other ignition sources. No smoking. } \\
9.1 \text { Information on basic physical and chemical properties } \\
\text { g) Flash point } 9.7^{\circ} \mathrm{C} \text { - closed cup. } \\
\text { j) Upper/lower flammability or explosive limits } \\
\text { Upper explosion limit: } 44 \% \text { (V). } \\
\text { Lower explosion limit: } 5.5 \% \text { (V). } \\
\text { 10.4 Conditions to avoid } \\
\text { Heat, flames, and sparks. } \\
\text { 10.5 Incompatible materials } \\
\text { Magnesium, zinc alloys, various plastics, strong oxidizing } \\
\text { agents. } \\
\text { 15.1 Safety, health, and environmental regulations/legislation } \\
\text { specific for the substance or mixture. National regulatory } \\
\text { information. } \\
\text { Fire Service Law: Group } 4 \text { : Flammable liquids, type } 1 \text { alcohol } \\
\text { hazardous rank II. }\end{array}$ \\
\hline $\begin{array}{l}\text { Oxidizing agent } \\
\cdot \mathrm{O}_{2}[22]\end{array}$ & $\begin{array}{l}\text { 2.1 Classification of the substance or mixture } \\
\text { Oxidizing gases (category 1). } \\
\text { Gases under pressure (compressed gas). } \\
\text { H270 May cause or intensify fire; oxidizer. } \\
\text { H280 Contains gas under pressure; may explode if heated. } \\
\text { P220 Keep/store away from clothing/combustible materials. } \\
\text { P410 + P403 Protect from sunlight. Store in a well-ventilated } \\
\text { place. } \\
\text { 10.5 Incompatible materials } \\
\text { Phosphorus, organic materials, powdered metals. }\end{array}$ \\
\hline
\end{tabular}




\section{DISCUSSION}

\subsection{Fire Example (1)}

The cause of the fire is thought to be thermal runaway resulting from an internal short circuit due to introduction of an external component as the result of an impact. The SDSs of the lithium-ion battery materials show that the battery's electrolyte is a flammable liquid, and that the separator is combustible.

If thermal runaway occurs in a system containing a flammable liquid, the risk of fire can be predicted; however, internal short circuit and thermal runaway cannot be predicted based on SDS information. Therefore, prediction of fire cases such as (1) solely with SDSs is difficult.

\subsection{Fire Example (2)}

In the case of fire example (2), the cause of the cabin fire that occurred prior to the rupture is unknown. However, it is clear that the heat from the flames in the cabin was transferred to the hydrogen container and hydrogen was released as the container ruptured, resulting in increased damage.

According to the SDSs, all of the used fuel gases are flammable. Moreover, the SDSs of hydrogen, CNG, and of the oxidizer oxygen warn that "explosion may occur if heated." From this information, it can be predicted that exposure of the fuel to a heat source is associated with a risk of explosion, resulting in a persistent fire.

Consequently, although a cabin fire is difficult to predict, SDS information enables prediction of the explosion fire due to the bursting of the compressed gas container. In order to prevent this fire, it is necessary to install multiple heat detectors on the end and center of the compressed gas container to enable the prompt detection of heat by a safety valve.

\subsection{Predictable and Unpredictable Fire Features}

The discussed examples show that fires caused by the substances contained in the battery can be predicted using SDS information on their properties. However, two types of fires cannot be predicted using SDSs alone. The first is a fire caused by thermal runaway, a phenomenon that can occur in batteries as a consequence of overdischarge or short circuit. However, thermal runaway can only occur when the individual components are assembled into a battery. It does not occur in the isolated components of the battery. Consequently, the hazard and safety information contained in the materials' SDSs does not allow prediction of fires resulting from thermal runaway. In the second case, the cause of the fire is unknown or artificial. Consequently, it is difficult to predict fires caused by factors other than materials those attributable to human error.

For example, Table 5 contains an excerpt of the SDS of methanol [21]. Formally, potentially dangerous temperature conditions may be: (1) higher than the flash point (g); 
(2) higher than the boiling point (f); and (3) higher than the melting point (e). Therefore, the "environmental temperature" immediately prior to an accident can be considered as one of the risk evaluation parameters.

Table 5 Excerpt of the SDS of methanol [21].

Methanol, CAS No. 67-56-1

9.1 Information on basic physical and chemical properties

a) Appearance Shape: liquid, Color: colorless

b) Smell: characteristic

c) Odor threshold (data not available)

d) No $\mathrm{pH}$ data

e) Melting point / freezing point Melting point / range: - $98^{\circ} \mathrm{C}$

f) Boiling point, initial boiling point and boiling range: $64.7^{\circ} \mathrm{C}$

g) Flash point: $9.7^{\circ} \mathrm{C}$ - Closed flash point test

- Tested according to European Command 92/69 / EEC Annex V.

h) Evaporation rate 6.3-diethyl ether 1.9-n-butyl acetate

i) Flammability (solid, gas): No data available

j) Upper / lower ignition limit or explosion limit:

Upper explosion range: $44 \%$ (V)

Lower explosive range: $5.5 \%(\mathrm{~V})$

k) Vapor pressure: $128 \mathrm{hPa}$ at $20^{\circ} \mathrm{C}$

Identification of typical conditions such as heating above the boiling point or the flash point and proximity to a flame may enable prediction of fires by sole use of the SDS data.

Moreover, commercially available lithium oxides were listed in Table 3 as potentially hazardous materials. According to reports on fire accidents, formation of lithium metal upon charge/discharge of batteries containing lithium oxides may be the cause of fire. As such, transformation of commercially available compounds by reactions not shown in their SDS limits the prediction feasibility.

\subsection{Prediction of Fires in Electric Vehicles Using AI}

Based on the characteristics of fires that cannot be predicted using SDS data, the design of AI fire prediction and initial fire extinguishing requires awareness for phenomena such as thermal runaway and possible chemical reactions, in addition to the battery material hazard information contained in the SDSs. Furthermore, AI should be fed with information on previous fire cases regarding the type of battery (not the material of their components) and effective fire extinguishing methods. As such, AI will be able to access the hazards of the battery material and pertinent examples of past accidents by searching for the name of the specific loaded battery when performing electric vehicle fire prediction. 
Furthermore, accidents have occurred overseas involving vehicles equipped with lithium-ion batteries. In May 2012, an electric car "e6" manufactured by BYD in Shenzhen, China, collided with a sports car. Following the collision the car ignited and burned, resulting in several casualties. BYD stated that the likely cause of the fire is a battery leak that occurred during the collision. In January 2013, a lithium-ion battery in an American airliner's Boeing 787 overheated and smoked during flight. The passenger plane made an emergency landing at Takamatsu Airport in Japan, as the instrument sensed smoke and generated an offensive odor [23].

Many other accidents should be considered for reliable results, and the development of AI for use in fire accidents is ongoing. Moreover, suitable examples of batterycaused accidents are limited at present. Therefore, the present discussion may favor conventional chemical knowledge-based predictions to AI predictions.

\section{CONCLUSION}

In the present study, we investigated whether past cases of electric vehicle fires could have been predicted using the information contained in the SDSs of the battery components. We also examined the problems that occurred when AI was fed with SDS data, and fire prediction and initial fire extinguishment of electric vehicles were performed. It was found that fires can be accurately predicted using SDS data, provided they are caused by the battery materials. In contrast, fires originated by thermal runaway or those resulting from artificial or unknown causes were difficult to predict.

In conclusion, in the future, when an AI-equipped system is utilized to predict fires in electric vehicles or perform initial fire extinguishing, it is not only necessary to assess the danger of the materials contained in the battery, but also the method used to extinguish the fire. Although the current study focused on electric vehicles, using AI to predict the risk of fire in other batteries and provide the corresponding information can be extended to all battery-equipped devices in future research.

\section{REFERENCES}

1. The Japan Fire Society, Fire Handbook 4th edition, Kyoritsu Publishing, 642-655, 2018 (in Japanese).

2. Tokyo Metropolitan Fire Department, December 22, 2016, Press Release Material Be careful of fires from lithium-ion batteries! (in Japanese).

3. Tadashi Watanabe, Basic Chemistry Course Electrochemistry, p. 150, 2018 (in Japanese).

4. Sigma-Aldrich Japan, Lithium-ion battery material, https://www.sigmaaldrich.com/ japan/materialscience/alternative/lithium-ion-batteries.html (cited 11/17/2019).

5. Sigma-Aldrich Lab \& Production Materials, Material Chemistry Fundamentals vol. 2, Fuel Cell Fundamentals and Evaluation Methods. 
6. Ministry of Internal Affairs and Communications Fire Agency, March 29, 2018, press release material, "Firefighting Disaster Prevention Science and Technology Advancement Strategy Plan 2018” announced.

7. Sigma-Aldrich Japan G.K., SDS of Lithium cobalt (III) oxide, https://www. sigmaaldrich.com/catalog/product/aldrich/442704?lang=ja\&region=JP (cited 11/17/2019).

8. Sigma-Aldrich Japan G.K., SDS of Lithium manganese oxide, https://www. sigmaaldrich.com/catalog/product/aldrich/725129?lang=ja\&region=JP (cited 11/18/2019).

9. Sigma-Aldrich Japan G.K., SDS of Lithium iron (II) phosphate, https://www. sigmaaldrich.com/catalog/product/aldrich/759546?lang=ja\&region=JP (cited 11/18/2019).

10. FUJIFILM Wako Pure Chemical Corporation, SDS of Carbon Nanotube, Single-

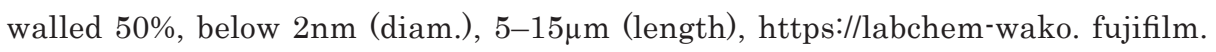
com/jp/product/detail/W01W0232-9400.html (cited 11/18/2019).

11. Sigma-Aldrich Japan G.K., SDS of Lithium titanate, https://www.sigmaaldrich. com/catalog/product/aldrich/765155?lang=ja\&region=JP (cited 11/18/2019).

12. Sangoban Co., SDS of Polyolefin porous membrane, http://www.tygon.saint-gobain. co.jp/pdf/msds_Tygon2475.pdf\#search=' Polyolefin +SDS (in Japanese) (cited 11/18/2019).

13. Sigma-Aldrich Japan G.K., SDS of Lithium hexafluorophosphate solution, https:// www.sigmaaldrich.com/catalog/product/aldrich/746754?lang=ja\&region=JP (cited 11/18/2019).

14. Sigma-Aldrich Japan G.K., SDS of Lithium hexafluorophosphate solution, https:// www.sigmaaldrich.com/catalog/product/aldrich/746762?lang=ja\&region=JP (cited 11/18/2019).

15. Sigma-Aldrich Japan G.K., SDS of Lithium hexafluorophosphate solution, https:// www.sigmaaldrich.com/catalog/product/aldrich/746770?lang=ja\&region=JP (cited 11/18/2019).

16. Sigma-Aldrich Japan G.K., SDS of Lithium hexafluorophosphate solution, https:// www.sigmaaldrich.com/catalog/product/aldrich/746789?lang=ja\&region=JP (cited 11/18/2019).

17. Sigma-Aldrich Japan G.K., SDS of Nafion ${ }^{\circledR}$ perfluorinated membrane, https:// www.sigmaaldrich.com/catalog/product/aldrich/274674?lang=ja\&region=JP (cited 11/18/2019).

18. Sigma-Aldrich Japan G.K., SDS of Nafion ${ }^{\circledR}$ perfluorinated resin solution, https:// www.sigmaaldrich.com/catalog/product/aldrich/510211?lang=ja\&region=JP (cited 11/18/2019).

19. Sigma-Aldrich Japan G.K., SDS of Hydrogen, https://www.sigmaaldrich.com/ catalog/product/aldrich/295396?lang=ja\&region=JP (cited 11/18/2019). 
20. The Linde group, SDS of Natural Gas, compressed, https://www.boconline.co.uk/en/ images/10021935_tcm41055840.pdf\#search='Natural+Gas\%2C+compressed.+SDS' (cited 11/18/2019).

21. Sigma-Aldrich Japan G.K., SDS of Methanol, https://www.sigmaaldrich.com/ catalog/product/sial/322415?lang=ja\&region=JP (cited 11/18/2019).

22. Sigma-Aldrich Japan G.K., SDS of Oxygen, https://www.sigmaaldrich.com/catalog/ product/aldrich/295604?lang=ja\&region=JP (cited 11/18/2019).

23. The Institute of Energy Economics, Japan, Fire accident with lithium-ion battery mounted on EV; thorough investigation of causes and countermeasures, April 16, 2013, https://eneken.ieej.or.jp/report_detail.php?article_info_id=4847 (cited 2/3/2020).

24. Kenta Mizuno, Kaori Ueki, Takashiro Akitsu, Case Studies on Predictability in University Chemistry Experiment Accidents, Fire Science and Technology, pp.1-16, No. 1, Vol. 37, 2018. 